\title{
Research on the Structure of China's Enterprise Income Tax Law System
}

\section{Yinying Wang}

S.J.D., University of Wisconsin-Madison, Law School, Madison, USA.

Email: wangyinying@gmail.com

Received March 25 ${ }^{\text {th }}$ 2011; revised May $7^{\text {th }}$, 2011; accepted May 15 ${ }^{\text {th }}, 2011$.

\begin{abstract}
The PRC enterprise income tax law was enacted on January 1, 2008, with accordance to which the enterprise income tax law system has been changing. It took a long time to promulgate the law just as it takes and will take certain period to integrate the system from the constitutional law to tax polices. The lack of taxing power under constitutional law, the silence of a basic tax law, and the arbitrary of tax policy issuance lead to an unstable structure of enterprise income tax law system. Lawmakers shall announce the taxing power under the constitutional law, form a general tax law, and take time to screen tax policies to improve the system.
\end{abstract}

Keywords: Enterprise, Income Tax Law, Restructure, Comparison

\section{Introduction}

Corporate income tax is a tax imposed for each taxable year on the taxable income of every corporation [1]. It is the term that widely used in the world, for example, known as Corporate Tax in the US. However, the term China adopts for the corporate income tax is "enterprise income tax", and it named the new law promulgate in 2008 the "Enterprise Income Tax Law of People's Republic of China" (hereinafter "EIT Law"). Imposed on various incomes of enterprises such as incomes from sales, services, interests, or the rental property [2], the tax is playing a more and more important role in China.

When talking about a law system, it refers to a set of rules dispersed among various statutes while they work together on a certain subject of law. As for the enterprise income tax law system, it may be composed of articles in the constitutional law clarifying the power of levying enterprise income tax, basic principles of imposing such taxes under the general tax act, the single enterprise income tax law, collecting measures concerning such taxes, and policies and rulings governing enterprise income taxes. If we collect those rules and classify them by sources, the conceptual shape of a system should be a pyramid [3], the most stable structure. The taxation article under the constitutional law sits at the top leading the basic tax law as well as enterprise income tax law followed by tax rulings and policies at the bottom. The lower the level is, the more rules are there in this level, but each level shall has appropriate number of regulations in order to keep the shape.

Apply pyramid theory to China's enterprise income tax law system. Besides the fact that the constitutional law is the mother law of all law fields, there is no basic law at the top while too many policies and rulings at the bottom in the enterprise income tax law department. Two laws, Enterprise Income Tax Law of the People’s Republic of China [4] and Law of the People's Republic of China on Tax Administration [5] (hereinafter "Tax Administration Law") lead the system. The former one is a substantive law while the latter is a procedural law. The next level has about 15 [6] effective administrative regulations, for example, Regulation on the Implementation of the Enterprise Income Tax Law of the People's Republic of China [7] (hereinafter "Implementation Regulation”). Last, 2997 [8] rules, explanations, circulars, and notices issued by both central government and local government sit in the bottom level such as the Notice of the State Administration of Taxation on Some Tax Treatment Issues during the Implementation of the Enterprise Income Tax Law [9]. Therefore, the proportion of pyramid is 0:2:15:2997.

Two major reasons contribute to this unstable structure. First, the enterprise income tax law system is under construction. Laws and regulations have been made, amended, or revised to meet the needs of society or economic development in the past decades. The same to the history 
of enterprise income tax law system development. Not only have great efforts been made to fill the blank of enterprise income tax law field such as the EIT Law was promulgated in 2008, but also regulations and rules have been expelled or organized to meet the WTO requirements, for instance, the State Administration of Taxation issued two notices to screen enterprise related tax rules, one in the year 2006 [10] and the other in 2008 [11], especially the second notice because the EIT law was enacted so that old policies under old laws could not be applied anymore. Such kind of adjusting is an ongoing process and will continue into the future.

The country's tax law system counters the similar situation and it is under construction as well. There is no basic law to lead the system; three laws occupy the next level, the individual income tax law [12], the EIT Law, and the Tax Administration Law; about thirty administrative regulations sit in the third level followed by more than 5500 explanations, notices, rules, measures at the bottom [3] The unstable structure occurs again, 0:3:30: 5500 , similar to the proportion of enterprise income tax law system. It is even worse that most specific taxes such as value-added tax, real estate tax, vehicle and vessel tax, etc. are governed not by laws but by interim regulations made by the State Council. For example, Interim Regulation of the People's Republic of China on Value Added Tax [13], Provisional Regulations of the People's Republic of China on Real Estate Tax [14], Provisional Regulations of the People's Republic of China on Business Tax [15], etc.

Second, the quick economic development involves arbitrary issuance of tax policies and rulings. China is making progress each year, accompany with which the market changes and becomes more and more sophisticated. Meanwhile, problems have appeared case by case, some of which have similar situation while others are particular or unique. Since making a new law requires complicated processes and is time-consuming, a quick and effective way instead is to issue policies. Moreover, it is unlikely to make laws for each case unless the problem goes wild in the country. That is the reason many explanations, measures, and notices have been issued to rule individual cases or to deal with particular law application problem.

The large amount of bottom-level rulings threatens the consistency of tax policies. Since they are issued under the corresponding economic environment or response to a particular case, a later ruling may, unfortunately, contradict with a former one without timely updating or noticing. Take the issue of foreign-funded enterprises purchasing domestic equipment to get tax credit for enterprise income tax as an example. On January 14, 2000, the Ministry of Finance and the State Administration of Tax- ation issued a tax deduction and exemption policy regarding foreign enterprises purchasing the domestic-made equipment [16]. However, such tax preferable measure was canceled when it comes to May 16, 2008 [17]. Because it was not regulated in the EIT law, so it is easy to be subject to change and not as stable as those measures under the law. Furthermore, tax reforms and tax reform trials have not been stopped these years. In order to provide instructions to difficulties during those periods, Department of Finance and State Administration of Taxation issued rules or policies daily. For example, 43 rules were issued in July 2004, 25 rules in August 2004, and 43 rules in September 2004 [3].

Three aspects compose the incompleteness of the structure of enterprise income tax law system: the lack of taxing power under constitutional law, the silence of a basic tax law, and the arbitrary of tax policy issuance. In the following sections, each aspect is discussed one after anther through introduction of countries with comparatively more sophisticated corporate income tax law system such as the US and the UK for the purpose of providing China with possible options for the restructure of the system. When the taxing power is announced under the constitutional law, a basic tax law is made, and tax rulings are simplified and consistent, the disproportionate layer of enterprise income tax law system will be fixed.

\section{Taxing Power under the Constitutional Law}

The power to tax is a basic incident of sovereignty [18]. A tax is primarily a means of raising revenue, and the power to tax involves the power to destroy [19]. Given such a characteristic, this power is normally controlled and limited by the constitutional law, the highest legal authority within the territory, and is exercised by the top legislature, such as the Congress or the perspective governing branch in individual countries. The purpose of such arrangement is to lower the possibility of power abuse in the democratic society. The enterprise income taxing power shall be part of it. However, such mechanism has not appeared in China.

In ancient times, it was easy for the King or Emperor to issue orders to levy taxes or to make changes because his orders were absolute regulation that all citizens had to obey, which prevented power limitation from being established [20]. Highly centralized government tended to the arbitrary use of tax privilege. At that time, the dominant concept was that all things within the country belonged to King. Therefore, he could decide when and how to take what from his people. Taxes were among these. People had no legal right to fight for ownership against the authority because their ownership was not protected. The powerless mass could only obey the order 
and pay taxes.

The situation had not changed until the foundation of Modern China [21]. It was the first time that the government attempted to regulate taxing power, not specifically enterprise income taxing power, under the constitutional law. However, the warlord era and the political struggle did not bring China into a democratic era [21]. As a result, the first trial failed [21]. The harsh social climate that lacked democracy, law and order substantially delayed the embodiment of ideal power in the constitutional law [21].

The stronger the centralized power was, the less possibility the limitation of power appeared. The similar situation appeared again under the planned economy after the country was founded [20]. No other power had the chance to balance it under such circumstances. To limit the central power's ability to impose taxes in any way such as through the Constitution was not possible.

The "reform and open-up policy" in 1978 began to change the country's economic and social structures, but it has not made any difference in regulating taxing power in the constitutional law till today. Only the obligation of citizens to pay taxes can be found under PRC Constitution [22]. The power to tax enterprises is not under the constitution.

Why is this regulation important? It is a significant factor in any democratic society ruled by law. Power is derived from and limited by the law in order to protect the rights of the people. Otherwise, it would be a repeat of ancient Chinese history when China was ruled by monarchy. Back then, the law was a tool to collect revenue whenever the monarch desired regardless of justification. For a long time, people did not realize the right to protect their own properties from being invaded until the ideals of democracy and individual rights became popularized. It aroused people's awareness of exercising their power to win back rights. Since then efforts have been made to implement checks and balances in the ruling political faction.

Constitutional law is supreme to all laws in a country and it regulates sources of powers. Basic principles, national affairs, fundamental rights of people and authorities of the government are included. A power that may limit the exercise of people's rights or the use of personal properties shall be declared under the constitutional law. The tax, especially the enterprise income tax, as the means of collecting revenue from people without considerations, belongs to this kind. Without the highest-level legal authorization, power is easily abused and the people would have been suffered, similar to the situation in the history. Therefore, the constitutional law, as the mother law in a country, has to take the responsibility to draw lines of imposing taxes with the due process.
Both the US and the UK have articles regulating taxing power under constitutional laws. The British Constitution, not written in one single document, is referred to as an uncodified constitution in the sense that it can be found in a variety of documents, which includes statutes such as the Magna Carta of 1215, the Act of Settlement of 1701, Laws and Customs of Parliament, political conventions, case law, and constitutional matters decided in a court of law or written by constitutional experts.

Magna Carta opens a new page of UK constitution by limiting king's power including imposing taxes to the law. Originally issued in the year 1215, it was the first document forced onto an English King John I by a group of the barons in an attempt to limit his powers by law and protect their privileges [23]. It bound the king to grant to all freemen the rights and liberties the great charter described, and with Magna Carta, King John placed himself and England's future sovereigns and magistrates within the rule of law [24]. It says, "No freemen shall be taken or imprisoned or disseised or exiled or in any way destroyed, nor will we go upon him nor send upon him, except by the lawful judgment of his peers or by the law of the land. To no one will we sell, to no one will we refuse or delay, right or justice" [25]. That means the principle that no one, including the king or a lawmaker, is above the law was established. In that case, no tax should be levied by the king arbitrarily but by the law and the people that being taxed on.

The 1688 Bill of Rights, along with the 1701 Act of Settlement the Bill of Rights remains, today, one of the main constitutional laws in the UK, which further ascertain the civil and political right that the agreement of parliament became necessary for the implementation of any new. "By Levying Money for and to the Use of the Crowne by pretence of Prerogative for other time and in other manner then the same was granted by Parlyament”, and "That levying Money for or to the Use of the Crowne by pretence of Prerogative without Grant of Parlyament for longer time or in other manner then the same is or shall be granted is Illegal” [26].

The Petition of Right is also a major English constitutional document, which was produced by the English Parliament in the run-up to the English Civil War, and was passed by Parliament in May 1628, and given the royal assent by Charles I in June of that year [26]. It sets out specific liberties that the king is prohibited from infringing, especially is most notable for its confirmation of the principles that taxes can be levied only by Parliament [27]. It identifies that, no person should be compelled to make any loans to the king against his will because such loans were against reason and the franchise of the land; none should be charged by any charge or imposition called a benevolence nor by such like charge by 
other laws of this realm as is provided; and no one should be compelled to contribute to any tax, tallage, aid, or other like charge not set by common consent in parliament by which statutes before mentioned and other the good laws and statutes of this realm [28].

Unlike the arrangement in United Kingdom, United States authorizes taxing power to the Congress under the codified Constitution. Article 1 section 8 Clause 1 was known as Taxation Clause, which says, the congress shall have power to lay and collect taxes, duties, imposts and excises, to pay the debts and provide for the common defense and general welfare of the United States; but all duties, imposts and excises shall be uniform throughout the United States. The Congress represents the people of the United States. Therefore, the right to tax is in the hands of its people.

Besides general taxation clause, the Unites States Constitution also authorizes the Congress the power to lay and collect taxes on incomes through the Sixteenth Amendment. It addresses that the Congress shall have power to lay and collect taxes on incomes, from whatever source derived, without apportionment among the several States, and without regard to any census or enumeration.

Taxing power clauses under constitutional laws generally concern all taxes instead of a particular one.

Therefore, they apply to corporate income taxes without any doubt. On the other hand, to levy corporate taxes within the power of the people through legal procedures in two countries reveal two different formations. In the UK, the power is put under several independent constitutional documents that claiming people's rights. However, the United States arranges the power in the Congress's rights part under the Constitution. Besides, the UK declares Parliament's consent to impose tax generally in its Constitution while the US further confirms Congress's power to lay tax on incomes especially because income tax always contributes the most internal revenue in the country since 1960 .

Except the UK and the US, there are two more types in regulating taxing power. One is the Italian Constitution that mentions people's obligation to pay taxes under the chapter of people's political rights but without the clause stating the power to tax. Under Part I Fundamental Principles, Title IV Political Rights, Article 53 says that everyone has to contribute to public expenditure in proportion to their capacity, and the tax system has to conform to the principle of progression. It is similar to China's current Constitutional Law.

The other type is represented by Japan's Constitutional Law, which includes people's obligation to pay taxes as well as the principle of no tax above the law. What Japan's constitutional law Article 30 says under Chapter III
Rights and Duties of People is that, the people shall be liable to taxation as provided by law. Chapter VII Finance, Article 84, however, addresses that no new taxes shall be imposed or existing ones modified except by law or under such conditions as law may prescribe. Thus, Japanese people are protected from being taxed without legal due process. But compare to the US or the UK constitutional laws, the government branch that is authorized to make laws to impose taxes is not assured.

The tax clause under China's Constitutional law only provides people's obligation to pay taxes, which is identical to the Italian Constitutional Law. It is under the chapter of people's rights and obligations. Nevertheless, it is not enough. Many scholars argue that basic principles regarding taxation have to be put in the constitutional law. For instance, fairness [29], no tax above the law [29], right of people to supervise tax collection [30], separation of taxing power between the central government and local government [30], transparency and efficiency [31], and basic collecting procedures [19], etc.

In my opinion, articles in the constitutional law should be general, simple and highly condensed since it is the mother law in a country's legal system. There is no need to specify any tax matters due to the particular need of taxation. Principles of fairness, transparent, efficiency or no tax above the law is suitable, but others such as basic procedures or separation of powers are too detailed to fit in. Another subject is very important that has to be put in the constitutional law, the judicial review over tax legislations. It is a good example of the functioning of separation of powers in a modern governmental system. Nevertheless, it is left blank in current China's tax law system.

China has been waiting for the appropriate time to change. Nowadays there are three reasons for the country to embody the taxing power and enterprise income taxing power into the PRC Constitutional law. First, civil society has been formed since the reform and opening-up policy that announced the beginning of open market economy has been a tremendous success. The administrative power in controlling market is not as strong as it was so that people are able to enjoy free trade and commerce while resources are circulated quickly [42]. Under such circumstances, people's awareness and willingness to embrace equality and self-protection is getting stronger against public authorities. The legitimate authority needs to clarify publicly, in an accepted and known powerful legal document that outlines the rights of the people.

Second, market economy provides a solid economic basis. Both the plan and the market have become active in resource allocation since Fourteenth Communist Party of China National Congress, and the market's role will 
be more active. Unlike after foundation of the country, for a long time, the government was said to represent the people to deal with official matters while it dominated all social activities in the country including production planning, resources allocation, commodity distribution, and decided the cost and profits for the next year's production even social benefits. Levying taxes were not helpful at that time because all economic activities were planned [33].

Finally, PRC constitutional law has confirmed the private ownership of citizen's legitimate property under Article 13, although the power to tax enterprises has not been included. It says that the state protects by law the right of citizens to own private property and the right to inherit private property; the state may, for the public interest, expropriate or take over private property of citizens for public use, and pay compensation in accordance with the law; the state protects according to law the right of citizens to inherit private property. It makes the government to respect the ownership of private properties and to protect them as well.

It was the 2004 constitution amendment that proudly added private ownership to this article, which has built a most concrete wall in protecting private domain, and is the catalyst for the development of civil society and democracy [34]. Before that, the article articulated: the state protects the right of citizens to own legal income, savings, houses and other lawful property; the state protects by law the right of citizens to inherit private property.

It is a great progress and opens a new page in the history. In the past, the original socialism required properties owned and shared by the people collectively. That is why the private ownership was driven out of the country before the opening up policy. It can be imagined that to respect private ownership at that time was incompatible with the country's political formation. As time goes by, market economy was adopted by the government, which needs the support of private enterprises. The more active the market is, the more appreciation has to be shown to the private properties.

Besides, article 8 of the Law on Legislation of the People's Republic of China limits the legislative power to tax. Those laws enacted by National People's Congress, so called "basic laws", have the authority to regulate the basic taxation system, not governmental rule or policy. According to article 26 of the PRC Constitution, the power to enact or amend basic laws belongs to National People's Congress. For example, the Fifth Session of Tenth People's Congress enacted the 2008 EIT law.

Therefore, taxing power shall be granted to nation's supreme legislative branch, the National People's Congress, while laws have to be passed to exercise the power.
These are fundamental power issues to be included in Chapter III The Structure of The State, Section 1 The National People's Congress together with the existing legislative powers. Thus, the arrangement of tax clause in the constitutional law is similar to Japan's type that the duty to pay taxes and the limitation of taxing power are both included. In the future, the country may need new rules or changes in the constitutional law, but for now it is the best arrangement for the top level in the enterprise income tax law system.

\section{The Making of a Basic Tax Law}

A basic tax law lays out basic principles of tax laws, which cannot be found in any legal documents right now; clarify authorities to issue explanations of laws, which is left blank in current system; draw lines among powers of public security, prosecution, or tax bureaus respectively when dealing with tax cases; regulate principles in both general and specific rules of tax case procedures [3]. Although as a code law country, China needs these general rules to help judges to form their opinions when the corresponding articles cannot be found anywhere else; to make the responsible government institutions to work without excuses; to guide the tax administration to follow due process. What is more important is that no sources can be found without such a law when applying lower level rules.

Countries like the US or the UK do not have basic tax laws. The US has one tax code featuring all tax rules while the UK has issued separate tax acts year by year. But other countries, like Russia, Germany, and Japan, have basic tax laws to define general principles and rules.

Russia enacted a basic principle law of Russian federal tax in 1991 and was replaced by Russia federal tax code [35] except four articles. The code is divided into two parts. Part I, considered as general rules, was enacted in 1999 [36]. It regulates tax system, tax obligators and authorities, tax elements, tax payment, administrative supervision, and legal liabilities in twenty chapters. Part II includes specific rules of corporate income tax along with other taxes, which took effect on August 5, 2000 [36].

Germany, however, published a single basic tax law with 415 articles under nine chapters [38]. It covers definitions and application rules, tax obligators and their duties, tax incentives, procedural rules of tax payment as well as tax collection, mandatory administrative execution, and criminal and administrative penalties with their procedures. Under the basic law, single tax laws are governed such as corporate tax law, income tax law, valued added tax law, and so on [37].

Japan has the similar arrangement to the Germany. It also has a basic tax rule named "Act on General Rules 
for National Tax” but with much less articles, 127 clauses in total. The rule has ten chapters ranging from general provisions, tax obligations, tax payment and collection, tax delay and return, surtaxes, tax adjustment, administrative and judicial procedures, to penalties [38]. Besides, Japan has single tax laws as well, such as Corporate Tax Act, Income Tax Act, Act on Special Measures Concerning Taxation, etc.

What is China's choice? The answer is definite either from scholars or the government that there has a great purpose for China to make a basic tax law. The National Taxation Administration responded by announcing the consideration of making a basic tax law in 1988. Since then, the proposal of making such a law has been submitted to the National People's Congress three times. Unfortunately, the drafting procedure is still under the process.

Scholars, on the other hand, have their own thoughts. Some think that the enactment of the law meets the requirement of rule-by-law; provides standards on common grounds for all specific tax laws; regulates important principles and the structure of the tax system; works as a substantive law with tax collection law as procedural law; brings a significant change to the system. Some argue that the law could fill the blank in the system though the tax law legislation has a long way to go; contributes to the legal system in the needs after entering WTO; provides an alternative for writing taxing power into constitution. Others state that the law may correspond to the principle of "no tax above the law"; may improve the tax system in a more scientific and systematic way; may make tax powers especially in administrative procedure under control and supervision.

I agree with all points of views stated above. But the scholars have raised the function of the law to a macro and abstract level, which makes it too great to be real or believable. I would rather express more practical and specific because the law is made for certain goals. The goal, I think, is that many important and common rules cannot be found anywhere in the system. For example, fundamental principles or rules that help judges to decide a case if no substantive article is applicable; the separation of powers among tax administrations, or between taxation administrations and other government institutions or public securities when a violation of tax law happens; and privileges in collecting taxes that are shared by central government and local government, which affect the use or flow of the tax revenue. Since there are areas left unregulated, the best way to make up for those opens is to make new laws. This is my explanation to the meaning of making a basic tax law in China.

Which model would China prefer, the US code model, or the single law style like German, Japan or Russia?
Voices from scholars are unanimous that they would pick up a single law model. The codified law is made when the legal system is complete or at least is stable otherwise the code has to be modified constantly. Taking into consideration that China is still constructing the tax system and for the convenience of amending, correcting, or deleting rules, it is better of leaving the substantive tax law and the procedural law separate instead of making a code but breaking its stability from time to time. Furthermore, China is a developing country with its first trial to make a basic tax law, a single and simple model will be more suitable than a complicated one although maybe the codification would be the final goal.

As for this issue, I would like to add a couple more points. Making a tax code like the U.S. IRC has its advantages since it may avoid contradictions or overlapping legislations to the large extent; however, the way is not realistic in China in short term. Many single tax rules have been made, and the codification process will take a lot of time, efforts, or costs, which is much more than making a new law. Apparently, it is not a wise choice to pick the difficult one. On the other hand, there are two types under the single law model, the German or Japan type and Russia type. The German or Japan model is more complex because both substantive and procedural rules are included while Russia model focuses on substantive rules only. What China needs is a basic substantive law parallel with the basic procedural rule, the tax collection law, to keep the balance under the system. Therefore, the model of Russia, the simple single basic tax law model, wins finally.

\section{The Screening of Tax Policies and Rulings}

Most enterprise income tax policies or rulings are issued by national tax administrations upon official opinions of applying rules. They are bridging over demands of individual taxpayers and the application of rules. When an enterprise income tax issue arises without recognized by laws, a ruling is used to explain how the case shall be dealt with. In the case that nowhere else could find any opinion on the situation, then rulings are required to fill the blank in the area. Countries like the US, the UK, Germany, and France circulate tax policies although forms and authorities in charge are different.

The United States has two government administrations to issue tax rulings. One of them is the Office of Tax Policy of the Department of Treasury. As one of its component office, the office assists the Secretary in developing and implementing tax policies, establishing policy criteria reflected in regulations and rulings and guides preparation of them with the Internal Revenue Service to implement and administer the Internal Revenue Code, and providing economic and legal policy 
analysis for domestic and international tax policy decisions [40]. The office is composed of two office, one of which is the Office of the Tax Legislative Counsel develops and reviews policy, legislation, regulations, revenue rulings, revenue procedures, and other published guidance dealing with all aspects of domestic federal income tax law [40].

The other is the Internal Revenue Service ("IRS"). The IRS is a bureau of the Department of the Treasury. It is organized to carry out the responsibilities of the secretary of the Treasury which has full authority to administer and enforce the internal revenue laws and has the power to create an agency to enforce these laws [41]. The mission of the IRS is to help America's taxpayers understand and meet their tax responsibilities; to correctly apply the laws enacted by Congress; to determine the reasonable meaning of various Internal Revenue Code provisions in light of the Congressional purpose in enacting them; and to perform this work in a fair and impartial manner, with neither a government nor a taxpayer point of view [42].

The Chief Counsel for the Internal Revenue Service provides advice to the IRS Commissioner on all matters pertaining to the interpretation, administration and enforcement of the Internal Revenue laws [43]. It prepares legislative proposals, regulations, revenue rulings and procedures, actions on decisions, and other items of public guidance and legal advice [43]. The branch that takes care of corporate taxes is the Associate Chief Counsel (Corporate) which is responsible for tax matters involving corporate organizations, reorganizations, liquidations, spin offs, transfers to controlled corporations, distributions to shareholders, debt vs. equity determinations, bankruptcies, consolidated return issues affecting affiliated groups of corporations [43]. It furnishes information, advice, and assistance in the development and drafting of internal revenue legislation [43]. It prepares revenue rulings, revenue procedures, announcements, notices, and news releases to be published for the guidance of taxpayers and Service personnel [43].

The Department of Treasury is entitled to enact tax regulations as well as policies while the IRS plays the main role in making tax policies and rules. Since IRS takes charge of tax administrative in practice, one of its core works is to interpret the Internal Revenue Code by issuing rules and policies. Rules involving substantive tax law is made in the Internal Revenue Bulletin in the form of Revenue Rulings while those procedural rules affecting taxpayers' rights or duties that relate to matters under the jurisdiction of the IRS is also published in the Bulletin in the form of Revenue Procedures [44].

The purpose of publishing Revenue Rulings and Revenue Procedures in the Internal Revenue Bulletin is to promote correct and uniform application of the tax laws by Internal Revenue Service employees and to assist taxpayers in attaining maximum voluntary compliance by informing Service personnel and the public of National Office interpretations of the internal revenue laws, related statutes, treaties, and regulations, and statements of Service procedures affecting the rights and duties of taxpayers [44]. However, there are exceptions when issues that answered by statute, treaty, or regulations; that answered by rulings, opinions, or court decisions previously published in the Bulletin; that are of insufficient importance or interest to warrant publication; determinations of fact rather than interpretations of law; that concerns informers and informers' rewards; or that disclosure of secret formulas, processes, business practices, and similar information [44].

The Internal Revenue Bulletin is the authoritative instrument to announce official rulings and procedures, acquiescences and nonacquiescences in adverse reported decisions of the United States Tax Court, and other Service pronouncements of general interest [44]. Also published in the Bulletin are other important tax matters such as Public Laws and related Committee Reports, Executive Orders, tax treaties, new or amended regulations (Treasury Decisions) and court decisions [44]. Taxpayers generally may rely upon Revenue Rulings published in the Bulletin in determining the applicability of the tax law to their own transactions and need not obtain ruling letters provided (a) the facts and circumstances in their cases are substantially the same, and (b) the positions stated in the Revenue Rulings are still determinative when considered in the light of subsequent legislation, regulations, court decisions, and Revenue Rulings [44].

Furthermore, rulings may be issued under certain circumstances in absence of regulations. For example, if the answer to the question raised is clearly covered in the Code; or, if the answer in the statute is not entirely free from doubt, but is reasonably certain. If doubt as to interpretation of the law governing the question cannot be reasonably resolved before the issuance of regulations, no ruling is issued.

All Internal Revenue Bulletins could be found on IRS website. When searching the publications by "Internal Revenue Bulletin”, there are 12,554 results listed. A huge number of rulings have been issued by IRS. When enter the search term "revenue ruling, corporate tax", 5420 results come out, almost one fourth of the revenue rulings.

In the United Kingdom, the HM Treasury and the HM Revenue \& Customs ("HMRC") are two government organizations dealing with taxes. The Treasury's main tax related job is to make bills [45] while HM Revenue \& Customs' is to issue publications and rules in daily practice [46]. HMRC, similar to IRS in the US, was formed 
on April 18, 2005, following the merger of Inland Revenue and HM Customs and Excise Departments, and the work is still continuing on their office-restructuring program [47]. They ensure the correct tax is paid at the right time, collect and administer direct taxes such as capital gains tax, corporation tax, income tax, inheritance tax, and national insurance contributions as well as indirect taxes, and so on [47].

In Germany, the Tax Department, also known as the Revenue Administration, is the public-sector body responsible for assessing and collecting taxes [48]. The Federal Ministry of Finance is the supreme authority of the Federal Revenue Administration, subordinate to which are various senior authorities which perform specific functions for which central government is responsible, such as the Federal Central Tax Office. Strictly speaking, the Federal Revenue Administration includes the Federal Ministry of Finance as the supreme federal authority, the senior federal authorities, the medium-level authorities, local authorities and other departments.

The tax authorities have the right to issue tax rulings. There are four kinds of rulings, the Binding Consent, the Information Request, the Actual Understanding, and the Good Faith [49]. These four types can be divided into two categories. One is binding ruling that includes the first two types, and the other is non-binding ruling that covers the latter two types.

Binding Consent is the form of binding ruling that is recognized by the German General Tax Act in connection with an audit [49]. As a result, it is limited to the evaluation of past facts, which have been reviewed in detail by the tax authorities. The Information Request is the type of ruling, upon which a taxpayer may base a legal claim, only pertains to any payroll tax which is to be withheld from wages and salaries as an advance payment by employers.

Actual Understanding is a type of arrangement between the taxpayer and the fiscal authorities, which does not permit any binding agreement regarding legal issues to be reached but to the concrete facts of the case and encompasses subjective intentions and conclusions [49]. The most significant implication of such an understanding or agreement in practice is in the prosecution or settlement of fiscal offenses [49]. The Good Faith only recognizes vague assumptions that by applying the principle of good faith, a commitment from the fiscal authorities as to previous actions may be achieved if such a situation was handled a certain way between the parties over many years [49].

France has two kinds of tax rulings, formal rulings and informal rulings. Formal rulings provide directions on tax benefits that are recognized by the law while informal rulings offer predicted results though no law confirms it
[3]. Most rulings are made by the General Tax Administration Directorate while the Tax Legislation Directorate, another ruling maker, usually regulates general explanations of tax law [3]. Generally, there are no procedural rules about how to obtain or publish tax regulations or rules, but taxpayers may request rulings according to substantive law articles or administrative documents because the development of France's rulings focuses on certain and reasonable expectations of taxpayers instead of administrative discretion.

In China, State Administration of Taxation (SAT) mainly takes charge of publishing tax policies and rules in form of "Notice" or "Reply". Since tax laws are in lack and rules that are supposed to be regulated by tax laws are now included in regulations, tax rulings are taking the position of both regulations as well as rulings. That makes rulings more than it should have.

As for enterprise income taxes, inconsistency and instability are results of issuing a huge number of tax rulings. The inconsistency is due to the two-tier system before January 1, 2008. That is, domestic enterprises are regulated by the PRC Interim Regulation on Enterprise Income Tax, enacted in the beginning of 1994, while foreign enterprises are ruled by the PRC Income Tax Law of Enterprise with Foreign Investment and Foreign Enterprise, published in April 1991. Many notices were issued for both laws, and even more to fill the gap between the two.

Moreover, tax policies changed a lot for foreign investment. For example, the tax incentive of tax refund to foreign enterprises when purchasing domestic equipment. The incentive was first published by SAT on September 20, 1999 to refund value added tax [50]. The next year, the incentive was extended to tax credit for enterprise income tax if purchase was for further investment [51]. Later, the administrative measure concerning tax credit for enterprise income tax was published by SAT on May 18, 2000 [52]. In 2004, the preferable measure was further awarded to enterprises that were not qualified in the previous rulings in order to include more foreign enterprises as an attractive measure [53]. After five years implementing the measure, many individual cases were reported to the SAT for specific rulings. For those have commons in certain industries, SAT issued two rulings in 2005 describing the application of the incentive under certain circumstances [54,55]. One year later, a notice redefining the scope of foreign enterprises and domestic products was distributed nationwide by the SAT to limit and clarify the application of the incentive [56]. Seven rulings were issued on one tax issue during seven years. The instability of tax rules is obvious. It was not stopped then. After the enactment of new EIT Law, both the measure of tax refund of value added tax and that of tax 
credit of enterprise income tax were abandoned in the year 2008 [57,58]. Meanwhile, a new tax incentive was made concerning value added tax refund for foreign funded projects when purchasing domestic made equipment on December 16, 2008 [59].

The legislative planning or other substitutive ways may help with the situation. When enterprise income tax system is improved with laws filled their positions, tax policies reduced, rules being consistent and stable, publishing new rulings will not be arbitrary but within the principles of tax laws and purposes. Take it pleasant, the promulgation of new EIT Law improves the situation a lot. The previous case is a good example. Many notices and replies were abandoned under the new law system.

However, another problem appeared. The screening of old rulings requires a long period of time and effort. Take the previous case as an example again. Though the incentive policy was discarded, seven notices were not all repealed but three of them were clearly announced to be not effective anymore in later rulings. It brings confusions whether the rest four are effective or not. Therefore, clearing old rulings shall launch as soon as possible to shorten the blurring period from transferring old system to the new one. Moreover, the process shall be set up routinely to make sure previous rulings are not conflicted or overlapped. It is a complex and time-consuming job for the reason that making many new rules is inevitable. Therefore, how to make it efficient and effective is the subject the government has to figure out.

\section{Suggestions of Restructuring the System}

Legal system is formed by rules from different legal sources. Legal sources are distinguished by powers that are authorized. China's constitutional law ranks at the top in the hierarchy followed by "basic laws" made by National People's Congress and other "laws" made by its standing committee. Article 62 of China’s Constitutional Law authorizes the National People's Congress the power to enact and amend basic laws governing criminal offenses, civil affairs, the state organs, etc. Article 67 of China's Constitutional Law authorizes NPC Standing Committee the power to enact and amend laws except those enacted by the National People's Congress. The level below "the law" is "the regulation" made by State Council. Article 89 of China's Constitutional Law authorizes State Council the power to adopt administrative measures, to enact administrative rules and regulations and to issue decisions and orders in accordance with the Constitution and the law.

Apply the mechanism structured by the constitutional law, China's ideal enterprise income tax law system should be as followed. The first level is constitutional law addressing the power to tax. The next level includes the basic tax law or both the basic tax law and the tax collection law, which are under the responsibility of National People's Congress. If China adopts the model to make the basic tax law as basic substantive law parallel to the tax collection law as basic procedural law, both basic tax law and tax collection law shall be in this level. If China chooses to make basic tax law into a general rule covering both substantive and procedural areas, only the basic tax law stands in this level. The third level includes the enterprise income tax law. The fourth level contains implementing measures that supplement to laws, known as Regulation on the Implementation of the Enterprise Income Tax Law of the People's Republic of China. The last level collects tax policies and rules issued by National Taxation Administration, Ministry of Finance, Ministry of Science and Technology and so forth.

Theoretically, China confronts difficulties to complete the system designed by the constitutional law in the second and third level. The tax collection law was made by NPC Standing Committee, which sits it in the category of the law rather than the basic law. How can it parallel with the basic tax law? On the other hand, the enterprise income tax law was made by National People's Congress, which categorized it into the second level instead of the third. Does this mean it is categorized in the same level with the basic tax law? Then how could it lead by the basic law? Individual income tax law is appeared in the appropriate position but most other specific tax rules are under the lower level.

Alternatively, redefine the system to make it feasible and not fall in the trap. That is to merge the second and the third level, at least they are all "laws" and no need to further divide them into basic or not basic, although there should be difference between the law made by the National People's Congress and that made by its standing committee, I think. This is an easy way but not the best choice. In my opinion, stick to the designed structure and consider it as a final goal. The country shall make the basic tax law as well as tax collection law while amend the enterprise income tax law. The project of improving China's enterprise income tax law system has been launched. We are happy to see the good beginning. However, it requires further contribution of work, time and costs. We look forward to further big leaps China's legislature will make in the future to solve the problem.

\section{REFERENCES}

[1] Internal Revenue Code (“IRC”) §11(a).

[2] J. M. Li, "The Categories of Incomes under Enterprise Income Tax Law,” In: Latest Questions and Answers Regarding Enterprise Income Tax, Law Press, Beijing, 2009. 
[3] J. W. Liu, "Basic Problems in China’s Taxation Legislation,” China Tax Publishing House, Beijing, 2006.

[4] "Enterprise Income Tax Law of the People’s Republic of China.” http://www.fdi.gov.cn/pub/FDI_EN/Laws/GeneralLawsa ndRegultions/BasicLaws/P020070327495400001563.pdf

[5] "Law of the People's Republic of China on Tax Administration."

http://www.chinatax.gov.cn/n6669073/n6669088/688798 1.html

[6] Put search term "Enterprise Income Tax" in the category "Administrative Regulation” of the powerful online legal document database in China.

http://www.chinalawinfo.com and got the result, 20 March 2009.

[7] "Regulation on the Implementation of the Enterprise Income Tax Law of the People's Republic of China". http://www.lawinfochina.com/law/display.asp?db=1\&id= 6546

[8] Put search term "Enterprise Income Tax" in the category "Administrative Institution Rule”, "Industrial Regulation”, "Local Administrative Regulation” and "Local Rule” of the powerful online legal document database in China. http://www.chinalawinfo.com and got the result, 20 March 2009.

[9] "Notice of the State Administration of Taxation on Some Tax Treatment Issues during the Implementation of the Enterprise Income Tax Law (Letter No. 202[2009] of the State Administration of Taxation).” http://www.lawinfochina.com/law/display.asp?db=1\&id= 7631

[10] The State Administration of Taxation, "The Notice of State Administration of Taxation on Issuing List of Abandoned or Ineffective Legal Rules Related to Taxation).” http://www.whgs.gov.cn/cms/whgs03/laws/01/030201/20 06-04-30.html

[11] The State Administration of Taxation, "The Second Notice of State Administration of Taxation on Issuing List of Abandoned or Ineffective Legal Rules Related to Taxation)."

http://law.chinalawinfo.com/newlaw2002/slc/slc.asp?db= chl\&gid $=102516$

[12] The Standing Committee of the National People's Congress, "Law of the People's Republic of China on Individual Income Tax,” 29 December 2007.

http://www.lawinfochina.com/law/display.asp?db=1\&id= 6575

[13] “Interim Regulation of the People's Republic of China on Value Added Tax,” 18 November 2008.

http://www.lawinfochina.com/law/display.asp?db=1\&id= 7170

[14] "Provisional Regulations of the People's Republic of China on Real Estate Tax,” 15 September 1986. http://www.lawinfochina.com/law/display.asp?db=1\&id= 1269

[15] "Provisional Regulations of the People's Republic of China on Business Tax,” 13 December 1993.
http://www.lawinfochina.com/law/display.asp?ID=626\& $\mathrm{DB}=1$

[16] "Notice of the Ministry of Finance and the State Administration of Taxation Concerning the Issue of Tax Credit for Enterprise Income Tax for Domestic Equipment Purchased by Foreign-Funded Enterprises.”

http://law.chinalawinfo.com/newlaw2002/SLC/SLC.asp? $\mathrm{Db}=$ chl\&Gid $=27135$

[17] "Notice of the State Administration of Taxation on Stopping the Implementation of the Enterprise Income Tax Deduction and Exemption Policy for the Investments of an Enterprise in Purchasing Home-Made Equipment.” http://law.chinalawinfo.com/newlaw2002/SLC/SLC.asp? $\mathrm{Db}=\mathrm{chl} \& \mathrm{Gid}=1053359$

[18] U.S. v. Alberts, 55 F. Supplement 217 (D.C.WASH. 1944)

[19] N. Redlich, J. Attanasio and J. K. Goldstein, "Constitutional Law,” 5th Edition, LexisNexis, New York, 2008.

[20] J. P. Bi, “A Discussion of Tax Constitutionalism in China,” Journal of AnHui University (Philosophy \& Social Science), Vol. 31, 2007, p. 52.

[21] S. Y. Chen, "Defects \& Perfection of Taxation,” Journal of Southwest University of Political Science \& Law, Vol. 1, No. 1, 1999, pp. 38-39.

[22] Constitution of People's Republic of China, "Duty to pay taxes (Article 56)."

http://www.usconstitution.net/china.html\#Article56

[23] "Magna Carta.”

http://en.wikipedia.org/wiki/Magna_Carta\#Temporary_pr ovisions

[24] “The Magna Carta.”

http://www.archives.gov/exhibits/featured_documents/ma gna_carta/

[25] "The Magna Carta (The Great Charter).” http://www.constitution.org/eng/magnacar.htm

[26] “Bill of Rights.” http://www.statutelaw.gov.uk/content.aspx?activeTextDo cId=1518621

[27] "Petition of Right." http://en.wikipedia.org/wiki/Petition_of_Right

[28] “The Petition of Right 1628.” http://www.constitution.org/eng/petright.htm

[29] J. W. Liu, "Suggestions on Taxation Constitutionalism in the Country,” Law Science Magazine, Vol. 25, No. 1, 2004, p. 77.

[30] J. De, "Taxation and Constitutional Law." http://www.lunwentianxia.com/product.free.4976616.2/

[31] S. T. Wang, "Discussion on Taxation under the Constitution,” ChangBai Journal, Vol. 6, 2004, p. 33.

[32] C. S. Ma, “Country, Civil Society and Rule by Law,” The Commercial Press, Shanghai, 2002.

[33] S. Y. Chen, "The Lack of Legalism of Taxation and Its Improvement," Journal of Southwest University of Political Science \& Law, Vol. 1, No. 1, 1999, p. 39.

[34] C. X. Quan and L. M. Yang, "Systemization and Its Re- 
alistic Meaning of Western Taxation Constitutionalism Concept,” HuNan Social Science, No. 3, 2005, p. 801.

[35] “Russian Federal Tax Code.” http://policy.mofcom.gov.cn/section/flaw!fetch.html?id=d 5b1e029-4681-4db5-9aa3-463c384bdccb

[36] L. C. Guo, "Russia Federal Tax System,” China Financial \& Economic Publishing House, Beijing, 2000.

[37] J. W. Liu and J. Y. Tang, “Analysis of Reference of General Tax Law of Germany to Legislation of China,” HeBei Law Science, Vol. 25, No. 4, 2007, p. 49.

[38] J. W. Liu and J. Y. Tang, "Contents and Reference of Act on General Rules for National Tax of Japan to China," International Taxation in China, Vol. 25, No. 12, 2007, pp. 118-120.

[39] “Mission.” http://www.ustreas.gov/offices/tax-policy/

[40] "Office of the Tax Legislative Counsel." http://www.ustreas.gov/offices/tax-policy/offices/tlc.shtml

[41] "The Agency, Its Mission and Statutory Authority." http://www.irs.gov/irs/article/0,,id=98141,00.html

[42] "Part 32, Published Guidance and Other Guidance to Taxpayers, 32.1.1.1 (08-11-2004) Role of Published Guidance in Tax Administration.” http://www.irs.gov/irm/part32/ch01s01.html

[43] "Part 1 Organization, Finance and Management, Chapter 1 Organization and Staffing, Section 6. Chief Counsel." http://www.irs.gov/irm/part1/ch01s05.html

[44] "Part 1 Organization, Finance and Management, Chapter 2 Servicewide Policies and Authorities, Section 16. Policy Statements for the Rulings and Agreements Process." http://www.irs.gov/irm/part1/ch02s10.html

[45] "HM Treasury, About Us, Ministerial Responsibilities", http://www.hm-treasury.gov.uk/miniprofile_htm

[46] "Review of HMRC’s Powers, Deterrents, and Safeguards." http://www.hmrc.gov.uk/about/powers-appeal.htm

[47] "HM Treasury, About Us." http://www.hmrc.gov.uk/menus/aboutmenu.htm

[48] "Welcome to Information and Services Concerning the Federal Fiscal Authority." http://www.steuerliches-info-center.de/en/003_menu_link s/003_BFINV/index.php

[49] A. Striegel and M. Weger, "Germany: Binding Rulings from the German Tax Authorities or the German Tax Airbag." http://www.mondaq.com/article.asp?articleid=28477

[50] "Notice of the State Administration of Taxation Concerning the Proposed Management Methods for Tax Refund.” http://www.lawinfochina.com/law/display.asp?db=1\&id= 2240

[51] "Notice of the Ministry of Finance and the State Administration of Taxation Concerning the Issue of Tax Credit for Enterprise Income Tax for Domestic Equipment Pur- chased by Foreign-Funded Enterprises.”

http://www.lawinfochina.com/law/display.asp?db=1\&id= 2239

[52] "Notice of the State Administration of Taxation on Distributing the Measures Concerning Enterprise Income Tax Credit on the Investment of Foreign-Funded Enterprises and Foreign Enterprises by Way of Purchasing Home Products.”

http://www.lawinfochina.com/law/display.asp?db=1\&id= 1029

[53] "Reply of the State Administration of Taxation on How to Apply the Provisions on Deduction and Exemption of Enterprise Income Tax on Purchase of Home-Made Equipment by Foreign-Funded Enterprises Whose Total Investment Have not been Approved.” http://www.lawinfochina.com/law/display.asp?db=1\&id= 3506

[54] "Notice of the State Administration of Taxation on Some Issues Regarding the Credit of Enterprise Income Tax against the Investment of Foreign-Funded Enterprises and Foreign Enterprises in Purchasing Home-Made Products."

http://www.lawinfochina.com/law/display.asp?db=1\&id= 4225.

[55] "Circular of the Ministry of Finance and the State Administration of Taxation on the Relevant Policies of Enterprises Income Taxes on the Purchase of Home-Made Equipment by Foreign-Funded Enterprises and Foreign Enterprises."

http://www.lawinfochina.com/law/display.asp?db=1\&id= 4407

[56] "Notice of the Ministry of Finance and the State Administration of Taxation on Adjusting the Scope of Tax Refund Policies for the Purchase of Home-Made Equipment for Foreign-Funded Projects."

http://www.lawinfochina.com/law/display.asp?db=1\&id= 5192

[57] "Notice of the Ministry of Finance and the State Administration of Taxation on Stopping the Implementation of the Policy of Refunding Tax to Foreign-Funded Enterprises for Their Purchase of Home-Made Equipment.” http://www.lawinfochina.com/law/display.asp?db=1\&id= 7292.

[58] "Notice of the State Administration of Taxation on Stopping the Implementation of the Enterprise Income Tax Deduction and Exemption Policy for the Investments of an Enterprise in Purchasing Home-Made Equipment." http://www.lawinfochina.com/law/display.asp?db=1\&id= 6805

[59] "Notice of the State Administration of Taxation and the National Development and Reform Commission on the Relevant Tax Refund Policies for Foreign-Funded Projects that Purchase Home-Made Equipment." http://www.lawinfochina.com/law/display.asp?db=1\&id= 7299 